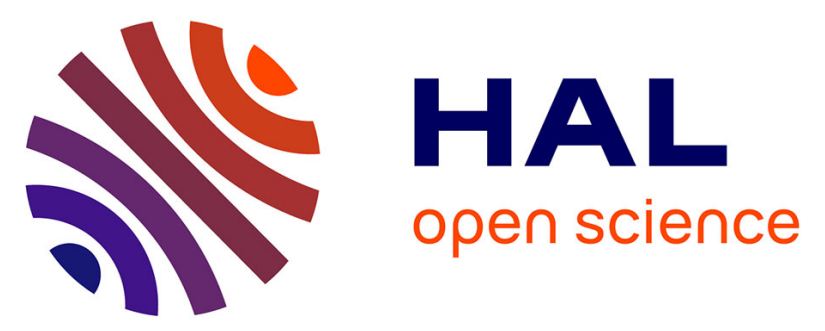

\title{
The importance of water availability in the reaction equilibrium of hydrolases in forest litters from a Mediterranean area: a study on lipases
}

\author{
Anne Marie Farnet da Silva, L. Qasemian, G. Gil, Elisée Ferré
}

\section{To cite this version:}

Anne Marie Farnet da Silva, L. Qasemian, G. Gil, Elisée Ferré. The importance of water availability in the reaction equilibrium of hydrolases in forest litters from a Mediterranean area: a study on lipases. European Journal of Soil Science, 2013, Greenhouse gas emissions from soil under changing environmental conditions, 64 (5), pp.661-666. 10.1111/ejss.12069 . hal-02069439

\author{
HAL Id: hal-02069439 \\ https://hal.science/hal-02069439
}

Submitted on 15 Mar 2019

HAL is a multi-disciplinary open access archive for the deposit and dissemination of scientific research documents, whether they are published or not. The documents may come from teaching and research institutions in France or abroad, or from public or private research centers.
L'archive ouverte pluridisciplinaire HAL, est destinée au dépôt et à la diffusion de documents scientifiques de niveau recherche, publiés ou non, émanant des établissements d'enseignement et de recherche français ou étrangers, des laboratoires publics ou privés. 


\title{
The importance of water availability in the reaction equilibrium of hydrolases in forest litters from a Mediterranean area: a study on lipases
}

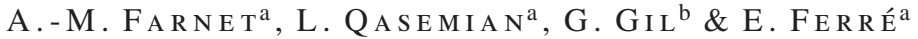 \\ anstitut Méditerranéen de Biodiversité et d'Ecologie marine et continentale (I.M.B.E.), Aix Marseille Université, UMR CNRS IRD \\ Avignon Université, Faculté de St-Jérôme, Marseille F-13397, France, and ${ }^{\mathrm{b} I S M 2}$ UMR CNRS, Aix-Marseille Université, Marseille \\ F-13397, France
}

\begin{abstract}
Summary
Water is one of the main variables affecting the carbon cycle (carbon storage or assimilation) in soils or litters from the Mediterranean area, though in most studies it has been considered via soil moisture measurements only. Here, we investigated the effect of water availability as characterized by water activity, $a_{w}$, on the equilibrium of enzyme reactions (hydrolysis/synthesis) for litters from three species characteristic of the Mediterranean area (Quercus pubescens L, Q. ilex L. and Pinus halepensis L.). Lipases were used as models and an organic phase was used as the reaction medium to adjust water amount. We found that the activities of hydrolysis/transesterification increased with $a_{w}$, showing that both can occur at the same $a_{w}$ in litter. Furthermore, these lipase activities in litter decreased for $a_{w}$ close to 1 , which has been described with purified lipases in organic media, indicating potential enzyme aggregation. Variations in $a_{w}$ with moisture were studied with sorption isotherms, which were found to be similar (isotherm type 2) for all the studied litters. Water activity is a crucial indicator for soils under hydric stress at small water contents, which should be considered for describing more precisely enzyme functioning and giving valuable information about carbon dynamics in soils or litters.
\end{abstract}

\section{Introduction}

Mediterranean ecosystems are subjected to severe climatic conditions, mainly characterized by long summer droughts. Moisture contents in soils or litters can thus vary strongly according to spatio-temporal patterns (Fioretto et al., 2001). Water influences the biological processes of organic matter transformation at different scales: microbial growth, enzyme production by microorganisms, protein conformation (Wehtje et al., 1997) and/or the equilibrium of certain enzymatic reactions such as hydrolases, for which water is a substrate of the reaction. For instance, lipases (EC 3.1.1.3) can catalyse either the hydrolysis or the synthesis of esters depending on the amount of water available. Summer drought may favour the synthesis pathway of lipase activity by limiting water availability, leading to carbon storage in litters through the esters produced. On the other hand, when amounts of water are greater (in spring or autumn under the Mediterranean climate), the hydrolytic activity of lipases may be enhanced and favour carbon assimilation (Smyth et al., 2011).

Correspondence: A. M. Farnet. E-mail: anne-marie.farnet@imbe.fr
While studies on enzyme activities in litters or soils have focused mostly on hydrolysis to assess carbon assimilation by microorganisms (Fioretto et al., 2000; Qasemian et al., 2012), considering the balance between synthesis and hydrolysis and its dependence on available water can be of major importance because it gives valuable information about the carbon cycle (carbon storage or assimilation). Moreover, water in environmental samples is, most of the time, characterized only as humidity, though mass loss after drying can result from volatile compounds and very tightly-bound water molecules can still be sorbed on soil particles. Taking into account the quantity of water actually available is possible using thermodynamic water activity, $a_{w}$, which is used widely in the food industry (Mathlouthi \& Rogé, 2003). Thermodynamic water activity can be defined as the ratio of water vapour pressure in the system over pure water pressure at constant pressure and temperature.

We suggest that $a_{w}$ may be a useful concept to apply to soils and the aim of this study was to investigate how $a_{w}$ may influence the reaction equilibrium of hydrolases in litter, using lipases as model enzymes. To do so, a reaction medium with organic solvent was used; this was of crucial importance because, under these 
conditions, the amount of water was controlled and thus, the influence of the water actually available in the litter on hydrolysis or transesterification can be described. Furthermore, by describing the relationship between humidity and $a_{w}$, we examined whether the chemical composition of litters of different plant species, Quercus pubescens L., Q. ilex L. and Pinus halepensis L., may affect water availability.

\section{Materials and methods}

Litter sampling: litters of Quercus pubescens (QP), Q. ilex (QI) and Pinus halepensis (PH) were collected as three composite samples for each species at Petit Sambuc (Var, France, $\left.43^{\circ} 37^{\prime} 17.868^{\prime \prime} \mathrm{N}, 5^{\circ} 39^{\prime} 1.835^{\prime \prime} \mathrm{E}\right)$ in February 2012. For each litter, horizon $\mathrm{L}$ was sieved ( $2 \mathrm{~mm}$ diameter). All the experiments described below were performed for each type of litter.

Water activities were measured in an incubator at $25^{\circ} \mathrm{C}$ with the Hygropalm probe (Rotronic, Fisher Scientific, Illkirch, France) using $2 \mathrm{~g}$ litter (fresh mass). In order to obtain different $a_{w}$ values, litter was gently dried at room temperature (around $22^{\circ} \mathrm{C}$ ) with a fan. Lipase activities (both hydrolysis and transesterification) were then measured from litters with the different $a_{w}$ values found. The litter moisture was measured after 72 hours of incubation at $80^{\circ} \mathrm{C}$ using $1 \mathrm{~g}$ fresh litter and was expressed as the percentage of water in fresh litter. The experiment was performed three times for each sample.

Lipase hydrolysis activities were measured as described by Farnet et al. (2010); this assay was adapted for litters from the method of Pencreac'h \& Baratti (1996) and using MTBE (methyltertiobutylether) as the organic solvent. The reaction mixture was $10 \mathrm{~mm}$-nitrophenyl laurate dissolved in $2 \mathrm{ml} \mathrm{MTBE}$ and $1 \mathrm{~g}$ litter. The reaction mixture was incubated at $30^{\circ} \mathrm{C}$ under magnetic stirring at $500 \mathrm{rpm}$ for 2 hours. Then, $500 \mathrm{ml}$ of the organic phase was added to $4 \mathrm{ml} 0.1 \mathrm{M} \mathrm{NaOH}$ and $p$-nitrophenol was measured at $412 \mathrm{~nm}$ with a spectrophotometer (Biomate; Fisher Scientific).

Lipase transesterification activities were based on an assay adapted for litters by Goujard et al. (2009) from the method described by Teng \& Xu (2007) and using also MTBE as the organic solvent. The reaction mixture was $10 \mathrm{~mm}$ of $p$-nitrophenyl laurate solubilized in MTBE, $400 \mu \mathrm{l}$ pentanol, $1 \mathrm{~g}$ of litter in $3.6 \mathrm{ml}$ MTBE. The protocol was the same as described earlier. Three replicates were performed for each experiment. Activities were expressed as $\mu$ moles of $p$-nitrophenol released per hour per $\mathrm{g}$ dry mass. A calibration curve of $p$-nitrophenol dissolved in MTBE was made with and without litter under the same experimental conditions.

Chemical characterization of litter was carried out by solidstate NMR of ${ }^{13} \mathrm{C}$; CP-MAS $13 \mathrm{C}$ NMR spectra were obtained on a Bruker DSX $400 \mathrm{MHz}$ (Bruker, Milano, Italy) spectrometer operating at $100.7 \mathrm{MHz}$. Samples $(600 \mathrm{mg})$ were spun at $10 \mathrm{KHz}$ at the magic angle. Contact times of $2 \mathrm{~ms}$ were applied with a pulse width of $2.8 \mu \mathrm{s}$ and a recycle delay of $3 \mathrm{~s}$. Chemical shift values were referenced to glycine signal (carbonyl $\mathrm{C}$ at $176.03 \mathrm{ppm}$ ). The

${ }^{13} \mathrm{C}$ NMR spectra were divided into seven chemical-shift regions according to Ziarelli (2004). Dmfit 2003 software was used to determine the intensity of each chemical-shift region (Massiot et al., 2002). An aromaticity ratio was also calculated to estimate the proportion of aromatic compounds in each litter (Baldock et al., 1997).

One-way ANOVA was performed to compare variations in hydrolysis and transesterification activities taking into account the type of litter (Quercus pubescens, Q. ilex and Pinus halepensis). Data were transformed as necessary to respect the normality and homogeneity of variance. Then pairwise comparison of means using Student's test was made. The peaks assigned to each chemical region of the NMR spectrum (COOH-C, aromatic-C, O-alkyl-C and alkyl-C) were compared taking into account the type of litter by using this procedure. Statistica Vs 6 (StatSoft, Maison-Alfort, France) was used for statistical analysis and $P$ values $<0.05$ were considered as being significant.

\section{Results}

Chemical characterization of litters from three Mediterranean species

Relative percentages of $\mathrm{COOH}-\mathrm{C}$, aromatic-C, O-alkyl-C and alkyl-C were calculated from the solid-state NMR data obtained from the three types of litter under study (Table 1). One-way ANOVA showed that the type of litter strongly influenced the amount of apolar molecules assigned to aromatic compounds (phenols) and lipids. More precisely, aromatic-C and alkyl-C signals were significantly larger in the Pinus halepensis and Quercus ilex litters, respectively. On the other hand, the O-alkyl signal, assigned to polysaccharides, was similar in the three types of litter.

\section{Sorption isotherms in litters}

The relationship between humidity and $a_{w}$ can be described using sorption isotherms. Figure 1 shows the isotherms found for the three litters and demonstrates that a similar pattern was obtained whatever the litter studied. These isotherms are characteristic of type-2 sigmoidal isotherms as described by Brunauer et al. (1940). This type of isotherm is characterized by the presence of multilayers of water molecules at the surface of a material. Here, and according to Brunauer et al. (1940), the sorption isotherms found can be described as follows: for $\mathrm{a}_{w}$ ranging from 0 to 0.2 , water is strongly bound to the material, from 0.2 to 0.6 , molecules of water are organized in multi-layers, and from 0.6 to 1 , molecules of water are free or loosely bound to the external surface of the multilayer.

\section{Variations in lipase activities dependent on $a_{w}$ and moisture content}

It is noteworthy that both hydrolysis and transesterification activities were detected at the same time for $a_{w}$ ranging from 0.2 to 1 and that the type of litter did not strongly influence 


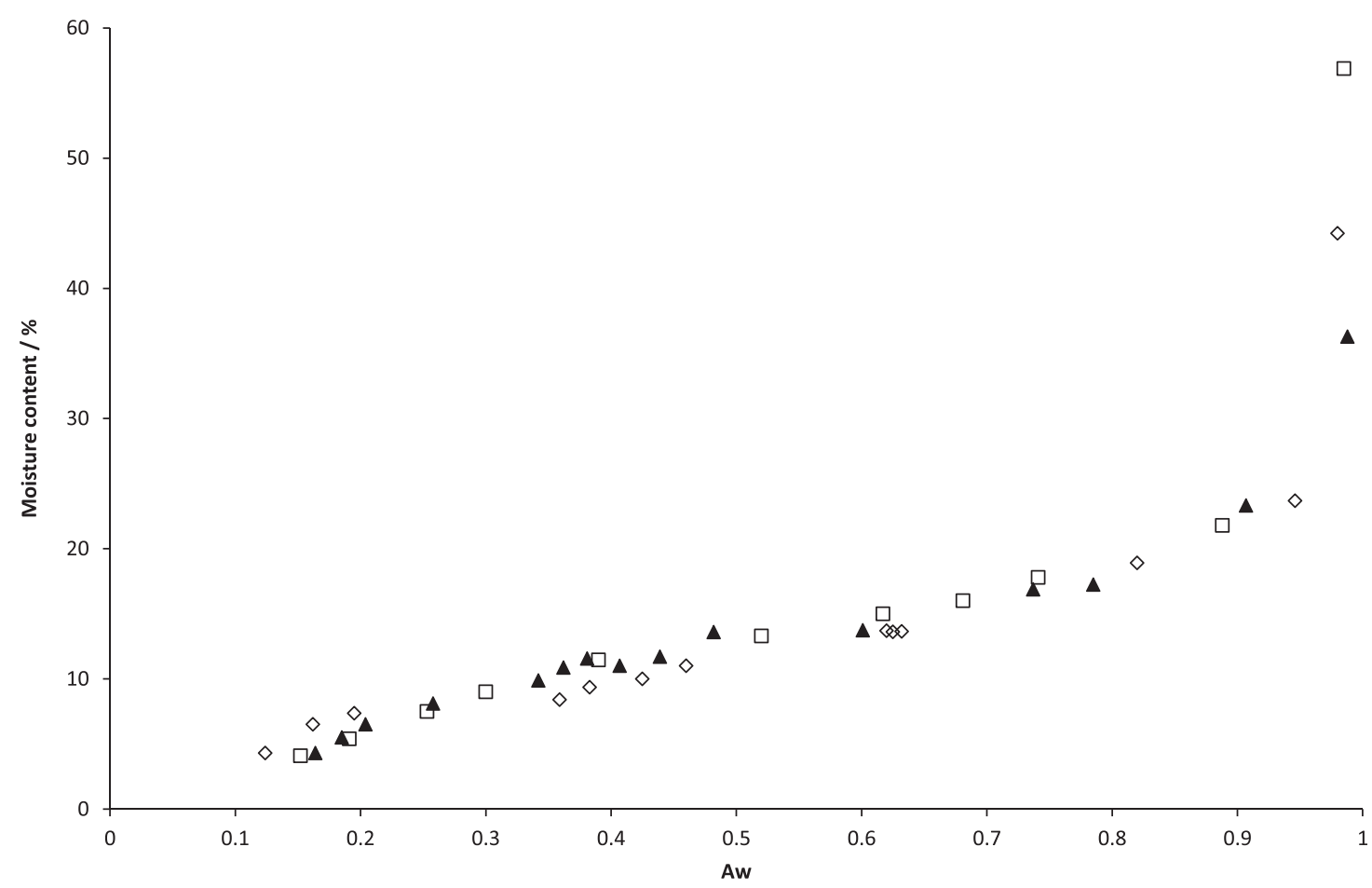

Figure 1 Sorption isotherms for litters of Pinus halepensis $(\diamond)$, Quercus pubescens $(\mathbf{\Delta})$ and $Q$. ilex $(\square)$. Each point is a mean of five values; standard deviations were $<3 \%$.

Table 1 Chemical characterization of litters of Pinus halepensis, Quercus pubescens and Q. ilex

\begin{tabular}{lccccc}
\hline (a) & COOH-C & Aromatic-C & O-Alkyl-C & \multicolumn{2}{l}{ Alkyl-C } \\
\hline Pinus halepensis & $4.53 \pm 0.07$ & $11.17 \pm 0.21$ & $58.92 \pm 1.02$ & $25.72 \pm 0.85$ \\
Quercus ilex & $8.21 \pm 0.32$ & $14.15 \pm 0.75$ & $61.79 \pm 2.01$ & $15.85 \pm 0.98$ \\
Quercus pubescens & $5.98 \pm 0.58$ & $9.2 \pm 0.90$ & $65.58 \pm 1.87$ & $19.26 \pm 0.74$ \\
\hline \multicolumn{7}{c}{ Sum of } & Mean & \\
(b) & d.f. & squares & square & F & $P$ \\
\hline Between controls & 2 & 0.954 & 0.460 & 3.56 & $<0.05$ \\
Within controls & 30 & 10.618 & 0.253 & & \\
Total & 32 & 11.538 & & &
\end{tabular}

(a) Averages of relative percentages and standard deviations of each chemical regions were calculated from solid-state NMR data (10 peaks for each chemical regions, $n=3$ ). (b) One-way ANOva on each chemical region as variables was performed.

the variations observed for both hydrolysis and transesterification activities (Figure 2a,b). These activities followed the same pattern, increasing with $a_{w}$, more strongly at values greater than 0.6 when the moisture content became more than $15 \%$ (Figure 2a,b).

The results of comparisons of means using ANOvA on both hydrolysis and transesterification activities showed that litter significantly affected both enzyme activities (Table 2). Moreover, pairwise comparison of means showed that both activities differed significantly between Quercus pubescens litters on the one hand and both $Q$. ilex and Pinus halepensis litters on the other (with $P<0.01$ in each case). The lipase activity patterns (both hydrolysis and transesterification) obtained from $Q$. pubescens litter were different from those observed in the $P$. halepensis or $Q$. ilex litters. These activities seemed to be less influenced by the increase in free water molecules from $\mathrm{a}_{w}=0.6$. For all the litters studied, a decrease in hydrolysis and transesterification activities was observed for water activities near, or equal to, 1 (Figure 3a,b). Here, quantitative differences in lipase activities between the different litters cannot be taken into account because variations in microbial communities resulting from the type of the litter may influence the enzymatic activity level.

\section{Discussion}

Water availability in litters from different vegetal species

We first investigated how the amount of available water, characterized by $\mathrm{a}_{w}$, varied with moisture content depending on the type of litter considered (from Quercus pubescens, Q. ilex or Pinus halepensis). We hypothesized that various percentages of polar molecules (such as polysaccharides and proteins) and apolar molecules (mainly aromatics and lipids) could be found in the structure of three different species typical of Mediterranean areas and thus could influence water sorption on the vegetal polymers. Here, a greater quantity of alkyl-C and aromatic-C was obtained for $P$. halepensis and $Q$. ilex litters respectively, which 
Table 2 (a) Means of hydrolysis and transestrification activities and standard deviations $(n=10)$ calculated for the three litters. (b) One-way ANova on both hydrolysis and transesterification activities of lipases as variables measured in litters of Pinus halepensis, Quercus pubescens and Q. ilex

\begin{tabular}{|c|c|c|c|c|c|}
\hline (a) & \multicolumn{2}{|c|}{ Means of hydrolysis activities $/ \mathrm{g}^{-1} \mathrm{DW}$} & \multicolumn{3}{|c|}{ Means of transesterification activities $/ \mathrm{g}^{-1} \mathrm{DW}$} \\
\hline Quercus pubescens & \multicolumn{2}{|c|}{$3.899 \pm 1.200$} & \multicolumn{2}{|c|}{$3.927 \pm 1.098$} & \\
\hline (b) & d.f. & Sum of squares & Mean square & $\mathrm{F}$ & $p$ \\
\hline \multicolumn{6}{|l|}{ Hydrolysis activities } \\
\hline Within groups & 25 & 11.372 & 0.455 & - & - \\
\hline Total & 27 & 56.494 & - & - & - \\
\hline \multicolumn{6}{|c|}{ Transesterification activities } \\
\hline Between groups & 2 & 45.572 & 22.786 & 58.934 & $<0.0001$ \\
\hline Within groups & 25 & 9.666 & 0.387 & - & - \\
\hline Total & 27 & 55.238 & - & - & - \\
\hline
\end{tabular}
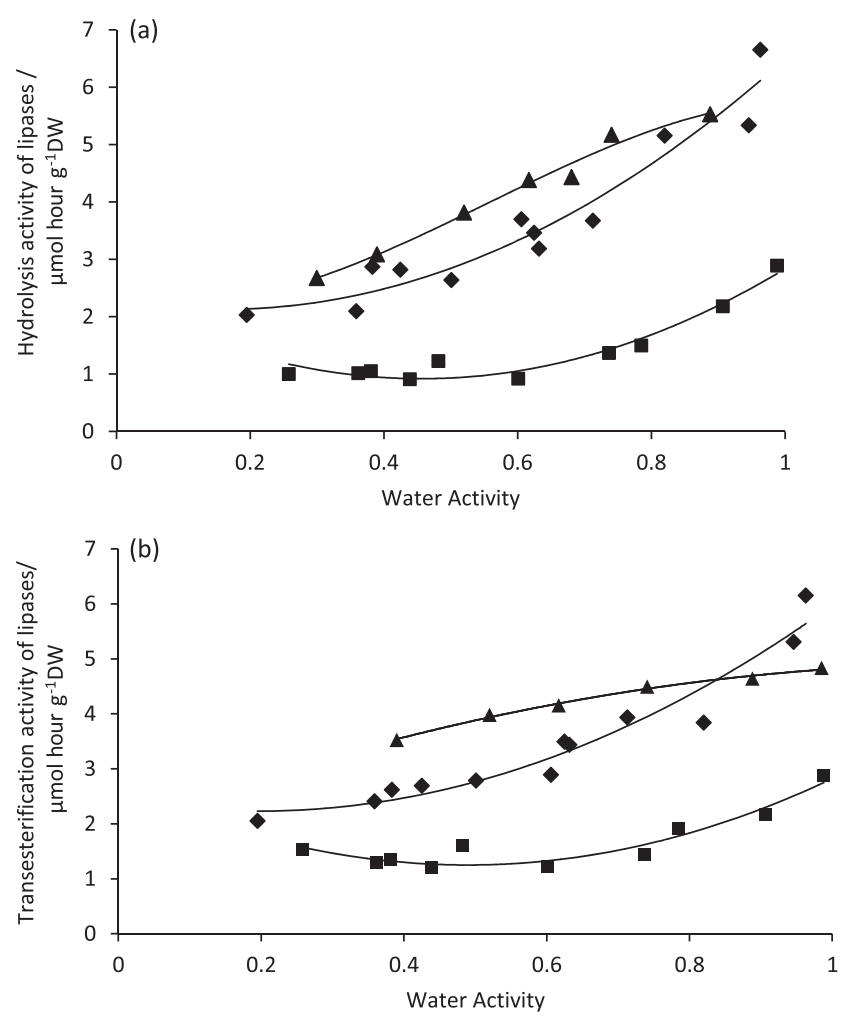

Figure 2 Hydrolysis (a) and transesterification (b) activities in litters of Pinus halepensis $(\bullet)$, Quercus pubescens $(\boldsymbol{\Delta})$ and Q. ilex $(\square)$ depending on $a_{w}$. Each point is a mean of three values; standard deviations were $<3 \%$.

has been reported before, although not demonstrated using solidstate NMR of ${ }^{13} \mathrm{C}$ (Coulis et al., 2009). However, these differences in chemical structure did not influence water sorption because a similar isotherm was obtained. Type-2 isotherms (Brunauer et al., 1940) are frequently found in food products but, to our knowledge, have never been described before for litters. This demonstrates that
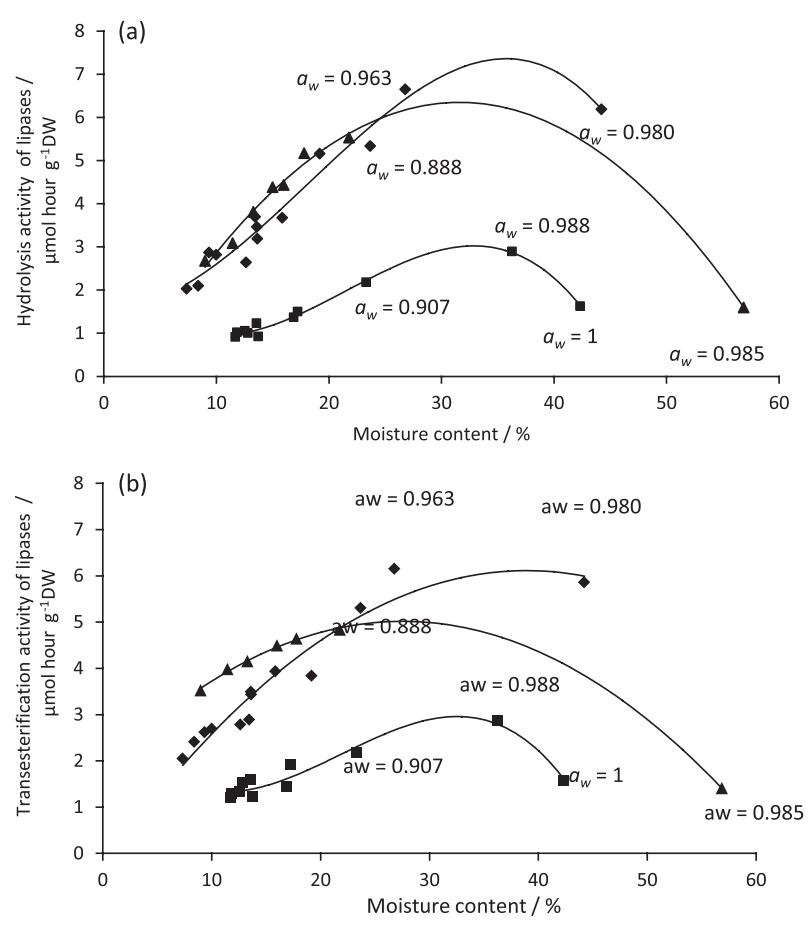

Figure 3 Hydrolysis (a) and transesterification (b) activities in litters of Pinus halepensis $(\diamond)$, Quercus pubescens $(\mathbf{\Delta})$ and $Q$. ilex $(\square)$ depending on moisture content. Each point is a mean of three values; standard deviations were $<3 \%$.

free water molecules are available in the three litters studied from $a_{w}$ values greater than 0.6 , because 0.6 is a point of inflexion of the curve, from which the shape of the sorption isotherm becomes concave (Mathlouthi \& Rogé, 2003). This can be linked with the results found considering variations in lipase activities, which increased from $a_{w}$ of 0.6. Free water is thus available for microbial activities from $15 \%$ of water content $\left(a_{w} 0.6\right)$ in litters from three typical Mediterranean species. 
Influence of $a_{w}$ on the balance between hydrolysis and transesterification activities of lipases

We hypothesized that the dynamics of hydrolysis and transesterification activities depend on the amount of water available and that a succession of activities (hydrolysis for larger $a_{w}$ values and transesterification for smaller $a_{w}$ ) may occur in litters. However, we found that both activities were taking place at the same time. This trend had also been observed by Chowdary \& Prapulla (2002) and Ma et al. (2002) with purified lipases (purchased from either Sigma Chemicals, St Louis, MI, USA, or Amano Enzyme Co. Ltd., Nagoya, Japan) from Candida rugosa and Rhizopus oryzae. We also found that both activities increased with $a_{w}$ and more precisely from $\mathrm{a}_{w}=0.6$; as noted earlier, sorption isotherms showed that free molecules of water were available from $\mathrm{a}_{w}=0.6$, which may favour both enzyme conformation and interaction with substrate. However, lipase activities in $Q$. pubescens litter were less influenced by the increase in free water molecules from $\mathrm{a}_{w}=0.6$; the chemical composition of this litter, with a smaller amount of apolar molecules than $Q$. ilex and Pinus halepensis litters, may have modified interactions between water, enzymes and the substrate. Physico-chemical characteristics of the material, such as porosity and hydrophobic molecule contents, strongly influence the effective moisture diffusivity (Roca et al., 2006). Thus here water mobility probably differs between the litter of $Q$. pubescens and that of $Q$. ilex and Pinus halepensis leading to a different pattern in lipase activities.

Chowdary \& Prapulla (2002) noted that the optimum $a_{w}$ for synthetic activities of lipases is strongly and positively correlated with the quantity of substrate. Thus, substrate concentration has a large effect on the optimum water activity controlled by any limitation of water's mass transfer. Here, a large concentration of $p$-nitrophenyl laurate was used (to reach concentrations for enzyme saturation), which explains a large optimum $a_{w}$ for the synthetic activities of lipases. In fact, the activities were measured here with a large amount of $p$-nitrophenyl laurate; under natural conditions, and for the same quantity of water, variations in lipase activities (both hydrolysis and transesterification) greatly depend on the relative proportion of available substrates, such as alcohols, acids or esters. From our results, we can conclude that both types of lipase activities potentially occur even for very small water activities (ranging from 0.2 to 0.4 ). Thus, carbon assimilation can still be realized via hydrolytic activities (though to a lesser extent) under drastic drought conditions (with moisture contents ranging from 10 to $20 \%$ ).

Under our experimental conditions, both lipase activities decrease for large water activity values. In organic media, the hydration level of enzymes strongly influences both hydrolysis and transesterification activities, which is probably linked to the effect of mass transfer as previously explained. Moreover, Yamane et al. (1989) have suggested that aggregation of lipases may occur for large water activities, leading to a decrease in enzyme reaction yields. In our previous study (Farnet et al., 2010), $2 \mathrm{ml}$ of water were added for hydrolysis quantification ( $a_{w}$ more than 1), which obviously optimized the hydrolysis reaction yields, the huge quantity of water favouring both enzyme conformation and reaction. Here, the reaction mixture with organic solvent was not complemented with water to measure hydrolysis activity; this allowed us to quantify the level of lipase hydrolysis activity obtained with water present only in the litter. Thus these experimental conditions may be more representative of enzyme activity levels potentially expressed in the field.

\section{Conclusion}

Thermodynamic water activity, $a_{w}$, should be taken into account to understand enzyme functioning under hydric stress better, as it implies experimental conditions that are more representative of in natura conditions by using an organic phase instead of the usual buffered aqueous-phase conditions. This study also demonstrated that certain enzymes can still be active at small water contents in litters. This has major relevance for understanding carbon dynamics in soils or litters and defining which conditions favour either carbon storage or assimilation. This balance in enzyme activities could be a useful indicator for soil management because it would determine how certain landscape uses (for both agrosystems and forests) could mitigate the effects of the climatic changes predicted through carbon storage in soils. This type of study should be extended to other enzymes such as glycosidases, which can catalyse both transglycosylation and hydrolysis.

\section{Acknowledgements}

We are very grateful to Mrs Marjorie Sweetko and Mr Patrick Fournier for their very helpful assistance with the English language for all these years and to Mr I.M. Da Silva for his technical support. We would like to thank Dr F. Ziarelli for solidstate NMR analysis. This work is dedicated to Oscar.

\section{References}

Baldock, J.A., Oades, J.M., Nelson, P.N., Skene, T.M., Golchin, A. \& Clarke, P. 1997. Assessing the extent of decomposition of natural organic materials using solid-state C-13 NMR spectroscopy. Australian Journal of Soil Research, 49, 1061-1083.

Brunauer, S., Deming, L.S. \& Teller, E. 1940. On a theory of Van derWalls adsorption of gases. Journal of the American Chemical Society, 62, 1723-1732.

Chowdary, G.V. \& Prapulla, S.G. 2002. The influence of water activity on the lipase catalyzed synthesis of butyl butyrate by transesterification. Process Biochemistry, 38, 393-397.

Coulis, M., Hättenschwiler, S., Rapior, S. \& Co, S. 2009. The fate of condensed tannins during litter consumption by soil animals. Soil Biology and Biochemistry, 41, 2573-2578.

Farnet, A.M., Qasemian, L., Goujard, L., Gil, G., Guiral, D., Ruaudel, F., et al.2010. A modified method based on $p$-nitrophenol assay to quantify hydrolysis activities of lipases in litters. Soil Biology and Biochemistry, 42, 386-389.

Fioretto, A., Papa, S., Curcio, E., Sorrentino, G. \& Fuggi, A. 2000. Enzyme dynamics on decomposing leaf litter of Cistus incanus and Myrtus communis in a Mediterranean ecosystem. Soil Biology and Biochemistry, 32, 1847-1855. 
Fioretto, A., Papa, S., Sorrentino, G. \& Fuggi, A. 2001. Decomposition of Cistus incanus leaf litter in a Mediterranean maquis ecosystem: mass loss, microbial enzyme activities and nutrient changes. Soil Biology and Biochemistry, 33, 311-321.

Goujard, L., Ferré, E., Gil, G., Ruaudel, F. \& Farnet, A.M. 2009. A method to quantify transesterification activities of lipases in litters. Journal of Microbiological Method, 78, 127-130.

Ma, L., Persson, M. \& Adlercreutz, P. 2002. Water activity dependance of lipases catalysis in organic media explains successful transesterification reactions. Enzyme and Microbial Technology, 31, 1024-1029.

Massiot, D., Fayon, F., Capron, M., King, I., Le Calve, S., Alonso, B., et al. 2002. Modelling one- and two-dimensional solid-state NMR spectra. Magnetic Resonance in Chemistry, 40, 70-76.

Mathlouthi, M. \& Rogé, B. 2003. Water vapour sorption isotherms and the caking of food powders. Food Chemistry, 82, 61-71.

Pencreac'h, G. \& Baratti, J.C. 1996. Hydrolysis of $p$-nitrophenyl palmitate in n-heptane by the Pseudomonas cepacia lipase: a simple test for the determination of lipase activity in organic media. Enzyme and Microbial Technology, 18, 417-422.

Qasemian, L., Guiral, D., Ziarelli, F., Van Dang, T.K. \& Farnet, A.M. 2012. Effects of anthracene on microbial activities and organic matter decomposition in a Pinus halepensis litter from a Mediterranean coastal area. Soil Biology and Biochemistry, 46, 148-154.
Roca, E., Guillard, V., Guilbert, S. \& Gontard, N. 2006. Moisture migration in a cereal composite food at high water activity: effects of initial porosity and fat content. Journal of Cereal Science, 43, $144-151$.

Smyth, C.E., Kurz, W.A., Trofymow, J.A. \& CIDET Working Group 2011. Including the effects of water stress on decomposition in the carbon budget model of the Canadian Forest Sector CBM-CFS3. Ecological Modelling, 222, 1080-1091.

Teng, Y. \& Xu, Y. 2007. A modified $p$-nitrophenyl palmitate assay for lipase synthetic activity determination in organic solvent. Analytical Biochemistry, 363, 297-299.

Wehtje, E., Costes, D. \& Adlercreutz, P. 1997. Enantioselectivity of lipases: effects of water activity. Journal of Molecular Catalysis B: Enzymatic, 3, 221-230.

Yamane, T., Kojima, Y., Ichiryu, T., Nagata, M. \& Shimizu, S. 1989. Intramolecular esterification by lipase powder in microaqueous benzene: effect of water content. Biotechnology and Bioengineering, 34, 838-843.

Ziarelli, F. 2004. Applications et développements des méthodes de résonance magnétique nucléaire haute résolution à l'état solide pour les matériaux organiques et inorganiques. Thèse de Doctorat, UniversitéAix-Marseille I, Marseille, France. 